\title{
PENGENALAN SHUGEI (JAPANESE HANDICRAFT) MELALUI PATCH WORK Di DESA CISEMPUR, KECAMATAN JATINANGOR, SUMEDANG
}

\author{
Pika Yestia Ginanjar, dan Riza Lupi Ardiati \\ Universitas Padjadjaran \\ E-mail: pika.yestia@unpad.ac.id
}

\begin{abstract}
ABSTRAK. Shugei berasal dari bahasa Jepang, terdiri dari dua huruf kanji (手) 'tangan' dan (芸) 'teknik' atau 'seni'. Shugei mulai dikenal di Jepang sekitar tahun ke-2 Meiji (sekitar tahun 1969). Shugei 手芸 merupakan sebutan untuk seluruh keterampilan dan seni kerajinan tangan yang menghasilkan barang-barang keperluan sehari-hari yang berada di dalam rumah, umumnya menggunakan kain dan benang. Misalnya, rajutan, dompet, keranjang, boneka, dan aksesoris kecil lainnya. Di Jepang, shugei biasanya dilakukan oleh wanita. Kegiatan ini tidak termasuk golongan pekerjaan tetapi termasuk kedalam hobi. Tujuan kegiatan PKM ini yaitu untuk meningkatkan kemampuan ekonomi Ibu-Ibu di desa Cisempur (RW 02), Kecamatan Jatinangor, selain untuk memperluas jaringan antara civitas akademi Unpad dengan masyarakat sekitar kampus. Mata pencaharian Ibu-Ibu di desa Cisempur (rw 02) sebagian besar bekerja di pabrik dan ibu rumah tangga.
\end{abstract}

Kata Kunci: Handicrafts, house production, patch work, shugei

ABSTRACT. Shugei is written in Japanese as 手芸, combining the character for hand (手) with the character for technique (芸 ). Shugei began to be known around the 2nd year of Meiji, or around 1969. Shugei is the name for all the skills and art of crafts that produce daily necessities which generally using cloth and yarn. For example, knits, wallets, baskets, dolls, and the other small accessories. The purpose of this PKM activity is to improve empower of the household production in Desa Cisempur (RW 02), Kecamatan Jatinangor. And besides to extending the network between scholar and local community. Mothers in the Desa Cisempur as many as their livelihood are factory employees, and housewives. Many of them find it difficult to produce some house production because they use their times to care for children.

\section{PENDAHULUAN}

Jawa Barat sejak dahulu dikenal dengan komoditaskomoditas yang berkualitas, dengan harga yang terjangkau. Banyak toko-toko yang selain membuka toko pada suatu tempat, mereka membuka pula layanan online shop, sehingga memudahkan para pembeli, terutama langganan mereka untuk medapatkan barang yang dicari. Banyak komoditas atau barang yang merupakan produk rumahan (Home made/ Hand made) termasuk kedalamnya adalah kerajinan tangan (crafts). Banyak diantaranya yang dijadikan sebagai cinderamata, maupun souvenir pernikahan.

Berangkat dari penelitian terdahulu mengenai pember-dayaan ekonomi rumah tangga melalui pemanfaatan daur ulang kain perca terhadap ibu-ibu PKK di desa Sayang, kecamatan Jatinangor (Ardiati dan Pika, 2017), mendapatkan apresiasi dan respon positif dari ibu-ibu yang mengikuti kegiatan tersebut. Kegiatan sebelumnya berfokus pada pembuatan aksesoris kecil, seperti bros, bantal jarum, dsb. Sedangkan kegiatan ini menitikberatkan pada pembuatan tempat tissue.

Desa Cisempur berada di wilayah Kecamatan Jatinangor Kabupaten Sumedang. Lokasinya terletak di bagian tanggara wilayah Kecamatan Jatinangor. Desa Cisempur berjarak sekitar lima kilo meter dari pusat Kecamatan Jatinangor, terletak di perbatasan antara Kecamatan Jatinangor dan Keca-matan Cimanggung.

Kegiatan PKM (Pengabdian Kepada Masyarakat) ini bertujuan meningkatkan daya usaha ibu-ibu yang berada di Desa Cisempur. Ibu-ibu di desa Cisempur sebaian mata pencahariannya adalah karyawan pabrik, dan ibu rumah tangga. banyak diantara mereka yang sulit berkegiatan karena mengasuh anak.

Shugei yang kami perkenalkan merupakan kerajinan yang tidak menghabiskan banyak waktu, juga tentunya dapat dilakukan di rumah. Sehingga dapat dilakukan di sela-sela mengasuh anak. Selain itu, bahan yang kami gunakan merupa-kan kain perca, atau kain sisa maupun kain bekas, sehingga kami berharap dapat mengurangi limbah pakaian di wilayah desa Cisempur khususnya dan Kecamatan Jatinangor pada umumnya.

\section{METODE}

Dalam kegiatan ini, kami mengkaji nilai-nilai yang terkandung dalam produk Shuugei Jepang, yang kemudian diaplikasikan secara langsung kedalam pembuatan souvenir dengan memanfaatkan patchwork. Diharapkan kegiatan ini dapat memperluas kesempatan ibu-ibu untuk menambah pengetahuan dan mengasah keahliannya dalam membuat barang kerajinan tangan.

Jepang memiliki beragam teknik yang digunakan untuk menghasilkan produk-produk berkualitas. Teknik tersebut diturunkan dari generasi ke genarsi hingga saat ini. Berikut adalah ringkasan sejarah kesenian dan keahlian keterampilan tangan di Jepang. (Asosiasi pengrajin Jepang, 2006).

[a] Zaman Jomon zaman Yayoi (10.000SM 3M); Pada zaman ini, menggunakan batu dan kayu sebagai bahan membuat senjata dan peralatan lain. Ketika memasuki zaman Yayoi, mulai memanfaatkan besi dan tembaga.

[b] Zaman Kofun zaman Nara (3M 8M); Pada zaman ini mengadopsi teknik memahat kayu dan tembaga.

[c] Zaman Heian (8M 12M); Pada zaman ini Jepang 
mulai membentuk seni orisinil dengan meningkatkan kualitas teknik di segala bidang keahlian dan kerajinan tangan. termasuk kedalamnya arsitektur dan pembuatan patung Budha, dengan memahat secara detil ekspresi muka dsb.

[d] Zaman Kamakura Muromachi (12M 16M); Pada zaman ini, para pendekar (Bushi) memiliki kedudukan tinggi di masyarakat, dan mulai masuk budaya minum teh. Sehingga mulai diproduksi cawan, dan peralatan lain, lalu mulai terbentuk rumah Jepang hingga sekarang masih dikenal.

[e] Zaman Azuchi Momoyama (16M 17M); Pengaruh Eropa mulai masuk di zaman ini. Keramik, magnet, dan seni bakar lainnya mulai tersebar luas di zaman ini.

[f] Zaman Edo (17M 19M); Zaman ini pemerintah menutup segala komunikasi dan perdagangan dari dan ke luar Jepang. Sehingga pengaruh dari luar negeri tidak lagi masuk ke dalam negeri, dan masyarakat Jepang mengasah teknik dan membentuk seni dan budaya Jepang di zaman ini. Motif pakaian, motif Jepang pada kimono, dan sebagainya.

[g] Zaman Meiji (19M 20M); Pada zaman ini, Jepang mengikuti Ekspo Internasional yang diselenggarakan di Austria, dan sejak saat itu, seni keterampilan Jepang, termasuk shugei, dikenal luas di Dunia.

[h] Zaman Taisho sekarang (sejak 20 M); Sejak zaman ini, Jepang mulai memadukan teknik tradisiolan dengan teknik dan model modern. Dan mulai membuka kelas-kelas pelatihan untuk meneruskan generasi.

\section{HASIL KEGIATAN}

1. Persiapan alat dan bahan.

a. Bahan kain; kami menggunakan kain polos dan kain bermotif agar dapat lebih mudah dipahami ketika praktek. Kain bermotif merupakan bagian muka, dan kain polos sebagai bagian belakang. Siapkan kain polos dan kain bermotif yang telah dipotong $(30 \mathrm{~cm}$ x $30 \mathrm{~cm})$.

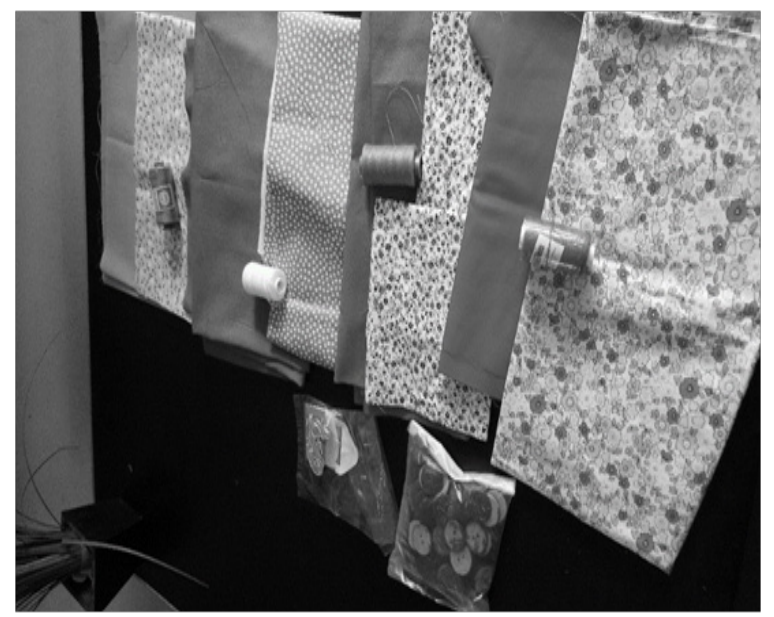

b. Peralatan; Benang yang warnanyadisesuaikandenganw arnakain, gunting, jarumjahit, matanenek, jarumpentul, dankancingsebagaiaksesoristambahan

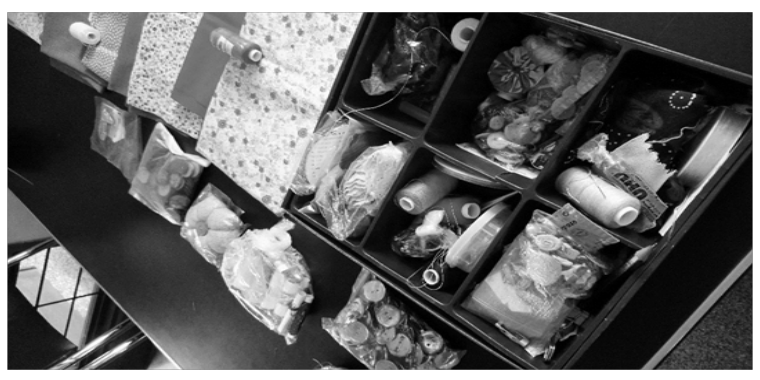

2). Tahapan pembuatan. Kami membuat Tempat tissue dalam pelaksanaan PKM ini. Tahapan pembuatannya adalah sebagai berikut:

1). Siapkan kain polos dan kain bermotif yang telah dipotong $(30 \mathrm{~cm}$ x $30 \mathrm{~cm})$.

2). Tumpukkan kedua kain tersebut, dan balikkan (polos di atas, motif di bawahnya)

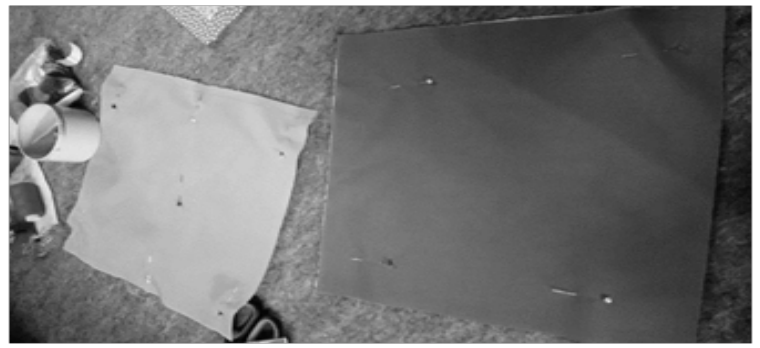

3) Sematkan jarum pentul pada beberapa sisi sehingga pada saat menjahit, kain tidak bergeser.

4). Jahit dengan membalikkan kain (kain polos di atas, kain bermotif di bawahnya). Pada saat menjahit, diawali dari ujung tepi kanan atas lurus horizontal kekiridan seterusnya hingga jahitan mengelilingi seluruh sisi kain. Sisakan kurang lebih $5 \mathrm{~cm}$, untuk memudahkan membalikkan kain.

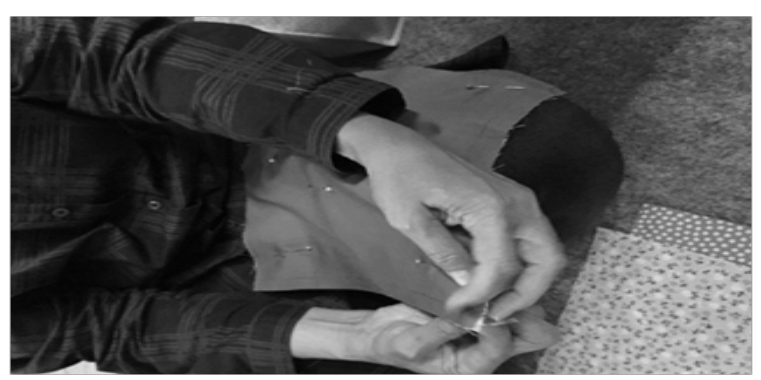

5). Matikan jahitan setelah sekeliling kain dijahit, lalu balikkan kain. (kain bagian dalam dikeluarkan sehingga jahitan berada dibagian dalam.

6). Lipat membentuk segitiga dengan kainpolos berada di bagian dalam, dan kain bermotif ada di bagian luar,

7). Beri tanda pada jarak $10 \mathrm{~cm}$ dari ujungnya, kemudian jahit pada dua titik tersebut,

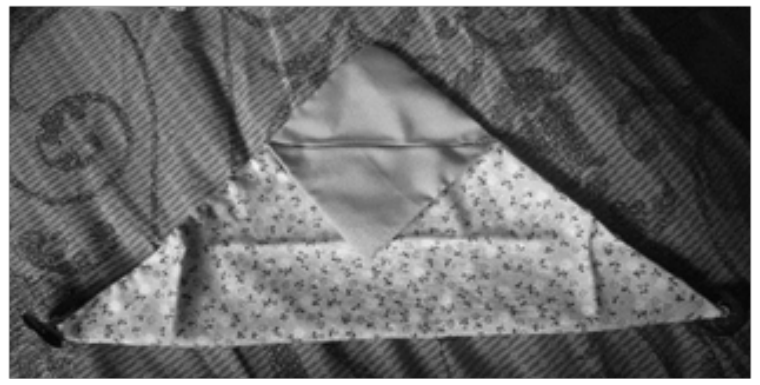


8. Tambahkan kancing pada dua ujung kanan-kiri sebagai aksesoris, lalu masukkan tissue kedalam.

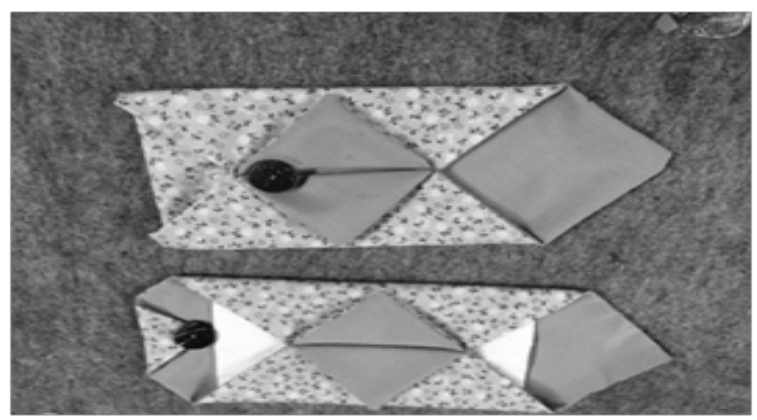

SIMPULAN

Dengan melaksanakan kegiatan ini, kami harap dapat mencapai target yang kami tuju, yaitu memberikan tambahan pengetahuan tentang shugei yang diaplikasikan secara langsung melalui patchwork kepada ibu-ibu PKK rw 2 Desa Cisempur. Kegiatan ini mendapatkan respon positif dari ibu-ibu PKK Desa Cisempur. Mereka dapat melakukan keterampilan shugei ini sambil mengisi waktu luang saat mereka menjaga anak-anak yang masih kecil. Bahkan mereka berkeinginan kegiatan ini berlanjut ke kesempatan selanjutnya, dengan membuat aksesoris lain. Respon positif ini tentunya didapatkan karena kegiatan ini termasuk kedalam kegiatan yang mudah pengerjaannya, murah karena dapat memanfaatkan kain perca dan menggunakan alat yang sederhana, serta waktu pengerjaannya pun tidak lama. Dan tentunya dapat menjadi tambahan pendapatan apabila produk hasil kegiatan dijadikan bahan komersil.

\section{Ucapan Terima Kasih}

Kami ucapkan terima kasih kepada Ibu Eri sebagai instructor pada saat mempraktekkan shuugei, serta kepada ibu kader dan ibu-ibu PKK Desa Cisempur RW 02.

\section{DAFTAR PUSTAKA}

Ardiati, Riza dan Pika 2017. Utilization Of Patchwork Recycle Through Patchwork Art Activity in Order to Motivate The Women Community in Sayang Village, Jatinangor. Jurnal Pengabdian Kepada Masyarakat. Vol. 1, No. 2, pp. 121 - 123

Dentouteki kougeihin sangyou fukkou kyoukai. (2006). Dentou kougei. Popura sha. (Asosiasi Pengrajin Jepang)

Kawakami, Seiko, dkk. 1999. Wakuwaku Wa No Fukuro To Komono. Tokyo: Seibido

Kimura, Kimiko. 2013. Hajimetedemo Yoku Wakaru Pacchiwaku. Tokyo: Pachiwaku Tsuushinsha

Nakamura, Jinan. 1996. Hajimete No PacchiWaku.Tokyo: Pachiwaku Tsuushinsha

Youko, Ueba. (2014). 新たな「手芸」の構築をめざして (Aratana “shugei”no kouchiku o mezashite). Minpaku Tsuushin. Vol. 11 